\title{
PURIFICATION OF URBAN WASTEWATERS BY HELLENIC NATURAL ZEOLITE
}

\author{
Filippidis A. ${ }^{1}$, Papastergios G. ${ }^{1}$, Apostolidis N. ${ }^{1}$, Filippidis S. ${ }^{1}$, Paragios I. ${ }^{1}$ \\ and Sikalidis C. ${ }^{2}$ \\ ${ }^{1}$ Aristotle University, Department of Mineralogy-Petrology-Economic Geology, 54124 Thessaloniki, Greece, \\ anestis@geo.auth.gr \\ ${ }^{2}$ Aristotle University, Department of Chemical Engineering, 54124 Thessaloniki, sikalidi@eng.auth.gr
}

\begin{abstract}
Treatment of urban wastewaters $\left(\mathrm{pH}_{\text {initial }} 8.2\right)$, with $6 \mathrm{~g}$ of Hellenic Natural Zeolite (HENAZE) of an grain-size $<1.5 \mathrm{~mm}$, gave overflowed clear water of $\mathrm{pH} 7.5$, free of odors and improved quality parameters by $87 \%$ for the suspended particles, $88 \%$ for the color, $91 \%$ for the $\mathrm{P}_{2} \mathrm{O}_{5}$ content, $93 \%$ for the chemical oxygen demand (COD) and $97 \%$ for the $\mathrm{NH}_{4}$ content. Compared to previous experiment, the decrease of the amount of HENAZE by $1.5 \mathrm{~g}(20 \%)$ resulted to the purification worsening only by $1-2 \%$. The HENAZE comes from Ntrista stream of Petrota village of Trigono Municipality of Evros Prefecture, Northeastern Greece. HENAZE contains 89 wt.\% HEU-type zeolite and exhibit an ammonia ion exchange capacity (sorption ability) of $226 \mathrm{meq} / 100 \mathrm{~g}$. The mineralogical composition and the unique physico-chemical properties, make the HENAZE suitable material for numerous environmental, industrial, agricultural and aquacultural applications, such as: Animal nutrition, soil amendment for agriculture, $\mathrm{pH}$ soil regulation, greenhouse and flowers substrates, durability and health improvement of lawn, purification of industrial and urban wastewaters, treatment of sewage sludge, odor control, fishery and fish breeding, gas purification and drying systems, oxygen enrichment of aquatic ecosystems, improvement of drinking water quality, constructed wetlands and wastewater treatment units. The treatment gave as precipitate an odorless and cohesive zeo-sewage sludge, suitable for safe deposition and also for the reclamation of agricultural soils. The zeo-sewage sludge, produced either from the urban wastewater treatment or from the mixing of HENAZE and sewage sludge, can be used for the reclamation of agricultural soils. The presence of HENAZE in the agricultural soils, increases the crops yield by $29-57 \%$ and improves the quality of agricultural products by $4-46 \%$, reduces the use of fertilizers by $55-100 \%$, reduces the usage of irrigation water by $33-67 \%$, prevents the seepage of dangerous species into the water environment (e.g., $\mathrm{NO}_{3}{ }^{-}$by 55-57\%), protecting thus the quality of surface and underground waters. The usage of HENAZE in vivarium units and in the animal nutrition, increases the production and improves the quality of the relevant products.
\end{abstract}

Key words: natural zeolite, urban wastewaters, sewage, sewage-sludge, Evros, Greece.

\section{Introduction}

Zeolite comprises a special solid crystalline microporous material, with open structure and void space. Some high quality HEU-type natural zeolites, displays unique physical and chemical features 
and have a great variety of environmental, industrial, aquacultural and agricultural applications. The large natural zeolite deposits and the low cost of mining, gave access to large-scale utilization (e.g., Pond and Mumpton, 1984; Tsitsishvili et al., 1992; Carr, 1994; Collela and Mumpton, 2000; Filippidis and Kassoli-Fournaraki, 2000; Bish and Ming, 2001; Harben, 2002; Savvas et al., 2002; Inglezakis and Grigoropoulou, 2004; Inglezakis et al., 2004, 2005; Filippidis, 2008; Filippidis et al., 2008e-g).

In the Trigono Municipality (Evros Prefecture, Northeastern Greece) and around the villages of Petrota and Pentalofos, eight different occurrences show varying zeolite contents, on average 39-76 wt. \% (e.g., Kirov et al., 1990; Marantos and Perdikatsis, 1994; Filippidis et al., 1995; Arvanitidis, 1998; Stamatakis et al., 1998, 2001; Filippidis and Kassoli-Fournaraki, 2000; Hall et al., 2000; Kassoli-Fournaraki et al., 2000; Yannakopoulos et al., 2000; Zorpas et al., 2000a,b; Barbieri et al., 2001; Moirou et al., 2001; Vlessidis et al., 2001; Koshiaris et al., 2002; Kyriakis et al., 2002; Papaioannou et al., 2002a,b; Savvas et al., 2002; Christidis et al., 2003; Katranas et al., 2003; Krestou et al., 2003; Perraki et al., 2003; Fokas et al., 2004; Inglezakis and Grigoropoulou, 2004; Inglezakis et al., 2004, 2005; Perraki and Orfanoudaki, 2004; Kantiranis et al., 2006; Warchol et al., 2006).

In a specific ground of Petrota village (Ntrista stream) has been located a HEU-type zeolite deposit, the Hellenic Natural Zeolite (HENAZE) of GEO-VET N. Alexandridis \& Co O.E. concession (e.g., Filippidis and Kantiranis, 2002, 2005, 2007; Deligiannis et al., 2005; Filippidis, 2005, 2007; Filippidis et al., 2006, 2007, 2008a-d, 2009). The purification of urban wastewaters, as well as the production of odorless zeo-sewage sludge, using 7.5 g of HENAZE and stirring time 5-60 min, has been investigated (Filippidis et al., 2008a-d, 2009). The present study investigates the purification of urban wastewaters, using $6.0 \mathrm{~g}$ of HENAZE and stirring time of $5 \mathrm{~min}$.

\section{Materials and methods}

The Hellenic Natural Zeolite (HENAZE) sample used was selected from a vertical profile of the Ntrista stream within the GEO-VET's concession. Petrographic investigation of HENAZE was performed on thin and polished thin sections. The morphology and chemistry of the HEU-type zeolite were studied by Scanning Electron Microscopy - Energy Dispersive Spectroscopy (SEM-EDS) with Link-AN 10000 EDS system. To minimize volatilization of alkalis, the electron beam spot size was enlarged and the counting time decreased. The mineralogical composition was determined by X-Ray Powder Diffraction (XRPD). Semi-quantitative estimates were performed using external mixture standards of the identified mineral phases (Filippidis and Kantiranis, 2007). The chemical composition of the HENAZE was determined by Atomic Absorption Spectrometry. The ammonia ion exchange capacity (sorption ability) of the HENAZE was determined according to the Ammonium Acetate Saturation (AMAS) method. The $\mathrm{pH}$ variations and the removal ability of metals and anions were performed through butch-type experiments at RT (Filippidis and Kantiranis, 2002, 2007; Filippidis, 2005; Filippidis et al., 2006).

The typical platy crystals of HEU-type zeolite have a grain-size of 5-25 $\mu \mathrm{m}$ (Fig. 1a, Filippidis and Kantiranis, 2002; Filippidis, 2005, 2007). The chemical formula of the clinoptilolite is $\mathrm{Ca}_{1.5} \mathrm{~K}_{1.4} \mathrm{Mg}_{0.6} \mathrm{Na}_{0.5} \mathrm{Al}_{6.2} \mathrm{Si}_{29.8} \mathrm{O}_{72} 20 \mathrm{H}_{2} \mathrm{O}$. The minerals content of HENAZE is 89 wt.\% HEU-type zeolite, 3 wt. $\%$ mica + clays (92 wt.\% microporous minerals), 6 wt. $\%$ feldspars and $2 \mathrm{wt} . \%$ quartz (Filippidis and Kantiranis, 2002, 2007; Filippidis, 2005). The chemical analysis of HENAZE gave: 68.62 wt. $\% \mathrm{SiO}_{2}, 11.80$ wt. $\% \mathrm{Al}_{2} \mathrm{O}_{3}, 2.92$ wt. $\% \mathrm{~K}_{2} \mathrm{O}, 2.14$ wt.\% $\mathrm{CaO}, 1.13$ wt. $\% \mathrm{Na}_{2} \mathrm{O}$ and 0.75 wt. $\% \mathrm{MgO}$. HENAZE shows a remarkable ammonia ion exchange capacity of $226 \mathrm{meq} / 100 \mathrm{~g}$, as well as an ability to neutralize the $\mathrm{pH}$ of basic water ( $\mathrm{pH} 9.5)$ from the lake Koronia (Prefecture of Thes- 

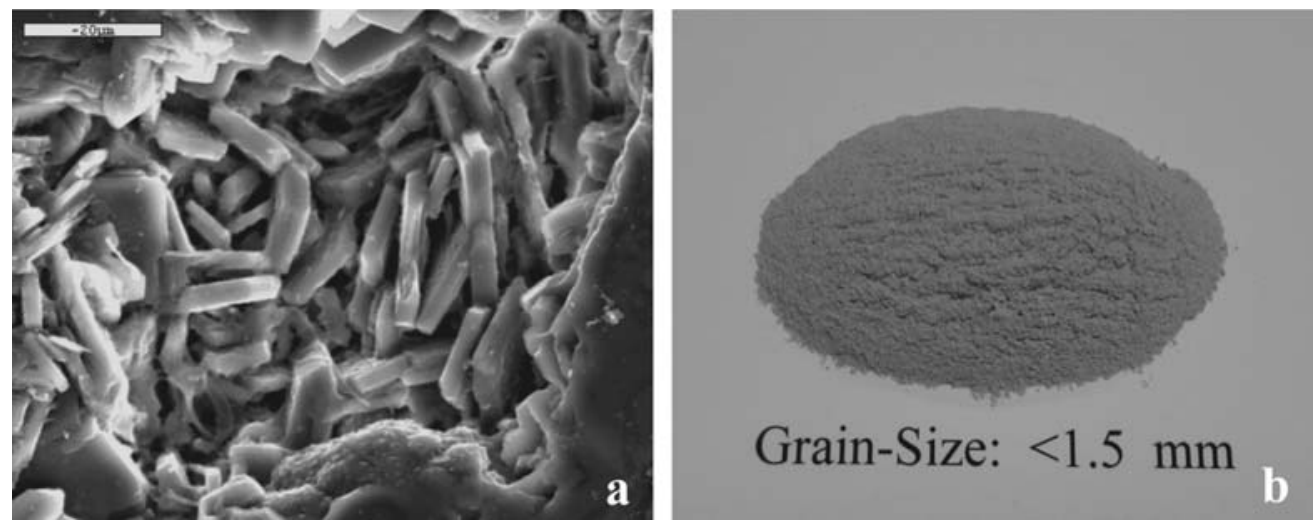

Fig. 1: a) SEM microphotograph of typical platy crystals of HEU-type zeolite of the HENAZE. b) The grainsize $<1.5 \mathrm{~mm}$ of HENAZE, used for the butch-type experiments.

saloniki) and of acidic stream mine water ( $\mathrm{pH}$ 5.5) from NE Chalkidiki Prefecture, exhibiting an amphoteric character (Filippidis and Kantiranis, 2002, 2007; Filippidis, 2005). Also found to remove from their aqueous solutions $74 \%$ of $\mathrm{Pb}, 79 \%$ of $\mathrm{Ag}$ and $55-57 \%$ of $\mathrm{NO}_{3}{ }^{-}$(Filippidis and Kantiranis, 2002, 2007; Filippidis, 2005; Filippidis et al., 2006).

Kilkis City (Northern Greece) urban wastewaters of $\mathrm{pH} 8.2$, were treated at room temperature with $<1.5 \mathrm{~mm}$ grain-size HENAZE (Fig. 1b), in butch-type experiment. In $300 \mathrm{ml}$ municipal sewage 6.0 $\mathrm{g}$ of HENAZE was added, the whole was stirred for 5 minutes and polyaluminium chloride as well as cationic polyelectrolyte was added. The overflowed clear water and the precipitated zeo-sewage sludge were separated by filtering. The zeo-sewage sludge was dried overnight at room temperature (RT). The starting urban wastewater and the overflowed clear water, were analyzed for (method): $\mathrm{pH}$ (electrometric), color (photometric), suspended particles (filtering and centrifugation), COD (method of $\mathrm{K}_{2} \mathrm{CrO}_{6}$ ), $\mathrm{P}_{2} \mathrm{O}_{5}$ and $\mathrm{NH}_{4}$ (molecular absorption spectrophotometry).

\section{Results}

Microscopic examination of thin sections reveals a fine-grained vitroclastic texture containing glass shards (Fig. 2), angular to subangular quartz and feldspar, as well as tabular mica crystals.

The lath- or tabular shaped crystals of HEU-type zeolite are very abundant as interstitial cements or as polycrystalline replacements of glass shards. The peripheral zone of the altered glass shards is often a rim containing clay minerals (Fig. 2).

The treatment of urban wastewater of pH 8.2 with the HENAZE gave overflowed clear water (Fig. 3a) of $\mathrm{pH} 7.5$, free of odors and improved quality parameters by $87 \%$ for the suspended particles, $88 \%$ for the color, $91 \%$ for the $\mathrm{P}_{2} \mathrm{O}_{5}$ content, $93 \%$ for the chemical oxygen demand (COD) and $97 \%$ for the $\mathrm{NH}_{4}$ content (Table 1).

Treatment with $7.5 \mathrm{~g}$ of HENAZE resulted to $\mathrm{pH}$ of 7.3 for the clear water and to improvement by $89 \%$ for the suspended particles, $90 \%$ for the color, $93 \%$ for the $\mathrm{P}_{2} \mathrm{O}_{5}$ content, $94 \%$ for the chemical oxygen demand (COD) and $98 \%$ for $\mathrm{NH}_{4}$ content (Table 1, Filippidis et al., 2009).

Simultaneously, the treatment gave as precipitate odorless and cohesive zeo-sewage sludge, dried overnight at room temperature (Fig. 3b). 


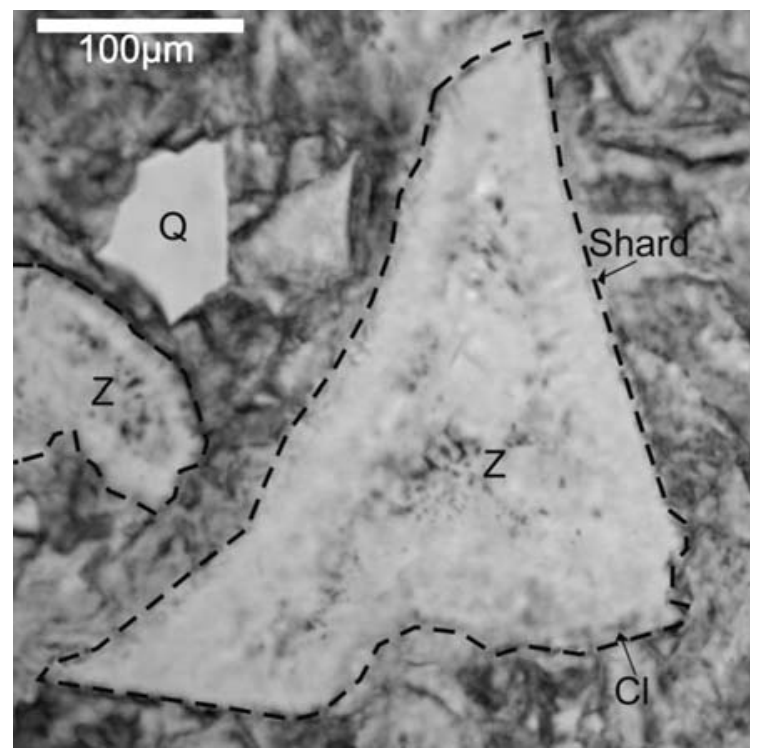

Fig. 2: Photomicrograph of thin section, altered glass shards (discontinuous line), lathtabular shaped crystals of HEU-type zeolite $(\mathrm{Z})$, angular-subangular quartz crystal $(\mathrm{Q})$ and the peripheral rim of the shards containing clay minerals $(\mathrm{Cl})$.
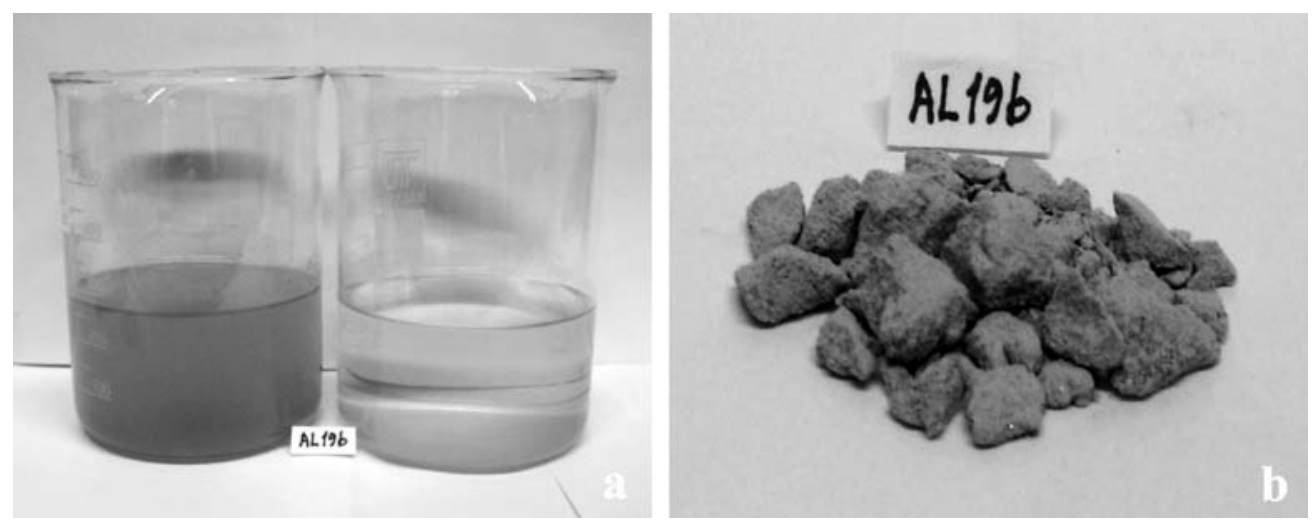

Fig. 3: a) Left: Starting urban wastewater (SUW), Right: Overflowed clear water (CW) after the HENAZE treatment. b) Odorless and cohesive zeo-sewage sludge, dried overnight at RT.

Table 1. Chemistry of starting urban wastewater (SUW) and overflowed relevant Clear Water treated with $6.0 \mathrm{~g}(\mathrm{CW}-6)$ and $7.5 \mathrm{~g}(\mathrm{CW}-7.5)$ of HENAZE at RT.

\begin{tabular}{|c|c|c|c|c|c|}
\hline Quality parameters (detection limit) & SUW & CW-6 & $\pm \%$ & CW-7.5* & $\pm \%$ \\
\hline $\mathrm{pH}(0.1)$ & 8.2 & 7.5 & -9 & 7.3 & -11 \\
\hline Suspended Particles, mg/L (5) & 210 & 28 & -87 & 23 & -89 \\
\hline Color, mg/L, Pt scale (5) & 1180 & 143 & -88 & 119 & -90 \\
\hline Chemical Oxygen Demand (COD), $\mathrm{mg} / \mathrm{LO}_{2}(15)$ & 410 & 29 & -93 & 26 & -94 \\
\hline $\mathrm{P}_{2} \mathrm{O}_{5}, \mathrm{mg} / \mathrm{L}(0.02)$ & 9.24 & 0.80 & -91 & 0.66 & -93 \\
\hline $\mathrm{NH}_{4}, \mathrm{mg} / \mathrm{L}(0.02)$ & 30.52 & 0.79 & -97 & 0.51 & -98 \\
\hline
\end{tabular}

* Filippidis et al., 2009. 


\section{Discussion and Conclusions}

The natural zeolites show a remarkable ability to remove inorganic, organic, organometallic compounds, gas species, metals and radionuclides from their aqueous solutions. The sorption of the different species from their solutions by the micro- meso- and macroporous of natural zeolite can be attributed to absorption (mainly ion exchange), adsorption and surface precipitation processes (e.g., Tsitsishvili et al., 1992; Misailides et al., 1993, 1995; Godelitsas et al., 1999, 2001, 2003; Collela and Mumpton, 2000; Bish and Ming, 2001). The sorption of gas phases results to oxygen enrichment of the air and to the remarkable decrease of the malodour. Also, they show an ability to neutralize the $\mathrm{pH}$ of acidic and basic waters, acting either as a proton acceptor or donor, exhibiting thus an amphoteric character (e.g., Filippidis et al., 1996; Charistos et al., 1997).

The Hellenic Natural Zeolite (HENAZE) is of very high quality (> 85 wt.\% HEU-type zeolite), removes inorganic, organic, organometallic, gas species, metals, cations and anions from their aqueous solutions. The mineralogical composition and the unique physico-chemical properties, make the HENAZE suitable material for numerous environmental, industrial, agricultural and aquacultural applications, such as: Animal nutrition, soil amendment for agriculture, conditioning of acid and basic soils, greenhouse and flowers substrates, durability and health improvement of lawn, purification of industrial and urban wastewaters, treatment of sewage sludge, odor control, fishery and fish breeding, gas purification and drying systems, oxygen enrichment of aqua ecosystems, improvement of drinking water, constructed wetlands and wastewater treatment units (e.g., Collela and Mumpton, 2000; Harben, 2002; Filippidis, 2007; Filippidis et al., 2007, 2008a-g).

The HENAZE treatment of urban wastewater ( $\mathrm{pH}$ initial 8.2) gave overflowed clear water of $\mathrm{pH} 7.5$, free of odors and improved by $87 \%$ for the suspended particles, $88 \%$ for the color, $91 \%$ for the $\mathrm{P}_{2} \mathrm{O}_{5}$ content, $93 \%$ for the chemical oxygen demand (COD) and $97 \%$ for the $\mathrm{NH}_{4}$ content. Treatment with $7.5 \mathrm{~g}$ of HENAZE resulted to $\mathrm{pH}$ of 7.3 for the clear water and to improvement by $89 \%$ for suspended particles, $90 \%$ for color, $93 \%$ for $\mathrm{P}_{2} \mathrm{O}_{5}, 94 \%$ for $\mathrm{COD}$ and $98 \%$ for $\mathrm{NH}_{4}$ (Filippidis et al., 2009). The decrease of the amount of HENAZE by $1.5 \mathrm{~g} \mathrm{(20 \% )} \mathrm{resulted} \mathrm{to} \mathrm{the} \mathrm{purification} \mathrm{worsening} \mathrm{only} \mathrm{by}$ $1-2 \%$. These final values of the $\mathrm{pH}$ and of the previous mentioned quality parameters, measured in the overflowed clear water, are fulfilling the requirements for disposition as downstream, irrigation, swimming and fish waters.

The HENAZE treatment gave also as precipitate, odorless and cohesive zeo-sewage sludge, suitable for safe deposition but also for the reclamation of agricultural soils. The same stands for the odorless and cohesive zeo-sewage sludge produced by mixing the sewage sludge and the HENAZE. The presence of HENAZE in the agricultural soils, increases the yield by $29-57 \%$ and improves the quality by $4-46 \%$ of agricultural products, reduces the use of fertilizers by $55-100 \%$, reduces the usage of irrigation water by $33-67 \%$, prevents the seepage of dangerous species into the water environment (e.g., $\mathrm{NO}_{3}{ }^{-}$by $55-57 \%$ ), protecting thus the quality of surface and underground waters. The usage of HENAZE in vivarium units and in the animal nutrition increases the production and improves the quality of their products (e.g., Filippidis, 2005, 2007; Filippidis et al., 2006, 2007, 2008c).

\section{Acknowledgments}

We express our gratitude to the GEO-VET N.Alexandridis \& Co O.E., for the supply and treatment of HENAZE, as well as for their economical support. 


\section{References}

Arvanitidis, N., 1998. Northern Greece‘s industrial minerals: production and environmental technology developments. Journal of Geochemical Exploration 62, 217-227.

Barbieri, M., Castorina, F., Masi, U., Garbarino, C., Nicoletti, M., Kassoli-Fournaraki, A., Filippidis, A. and Mignardi, S., 2001. Geochemical and isotopic evidence for the origin of rhyolites from Petrota (Northern Thrace, Greece) and geodynamic significance. Chemie der Erde 61, 13-29.

Bish, D.L. and Ming, D.W., 2001. Natural Zeolites: Occurrence, Properties, Applications. Mineralogical Society of America, 654 pp., Washington DC.

Carr, D.D., 1994. Industrial Minerals and Rocks. Braun-Brumfield Inc., 1196 pp., Ann Arbor, Michigan.

Charistos, D., Godelitsas, A., Tsipis, C., Sofoniou, M., Dwyer, J., Manos, G., Filippidis, A. and Triantafyllidis, C., 1997. Interaction of natrolite and thomsonite intergrowths with aqueous solutions of different initial $\mathrm{pH}$ values at $25^{\circ} \mathrm{C}$ in the presence of $\mathrm{KCl}$ : Reaction mechanisms. Applied Geochemistry 12, 693-703.

Collela, C. and Mumpton, F.A., 2000. Natural Zeolites for the Third Millenium. De Frede Editore, 481pp., Napoli.

Christidis, G.E., Moraetis, D., Keheyan, E., Akhalbedashvili, L., Kekelidze, N., Gevorkyan, R., Yeritsyan, H. and Sargsyan, H., 2003. Chemical and thermal modification of natural HEU-type zeolitic materials from Armenia, Georgia and Greece. Applied Clay Science 24, 79-91.

Deligiannis, K., Lainas, Th., Arsenos, G., Papadopoulos, E., Fortomaris, P., Kufidis, D., Stamataris, C. and Zygoyiannis, D., 2005. The effect of feeding clinoptilolite on food intake and performance of growing lambs infected or not with gastrointestinal nematodes. Livestock Production Science 96, 195-203.

Filippidis, A., 2005. Mineralogy and physico-chemical characteristics of five natural zeolite samples for N. Alexandridis \& Co O.E. Internal report, 10 pp., Thessaloniki, In Greek.

Filippidis, A., 2007. Zeolites of Trigono Municipality of Evros Prefecture in industrial, agricultural, cattle-raising and environmental technology. Proceedings, Scientific Meeting on Development Perspectives of Northern Evros, Petrota, Greece, 89-107, In Greek.

Filippidis, A., 2008. Treatment and recycling of municipal and industrial waste waters using Hellenic Natural Zeolite: A Review. CD-Proceedings, AQUA 2008, $3^{\text {rd }}$ Intern. Conf. Water Science and Technology, Athens, 5 pp.

Filippidis, A. and Kantiranis, N., 2002. Morphology, mineralogy, chemistry, mineralchemistry and ion exchange capacity of five natural zeolite samples for N. Alexandridis \& Co O.E., Internal report, 5 pp., Thessaloniki, In Greek.

Filippidis, A. and Kantiranis, N., 2005. Industrial, agricultural and environmental uses of the natural zeolites of Thrace. Bull. Geol. Soc. Greece 37, 90-101, In Greek with English summary.

Filippidis, A. and Kantiranis, N., 2007. Experimental neutralization of lake and stream waters from N. Greece using domestic HEU-type rich natural zeolitic material. Desalination 213, 47-55.

Filippidis, A. and Kassoli-Fournaraki, A., 2000. Environmental uses of natural zeolites from Evros district, Thrace, Greece, Proceedings, $5^{\text {th }}$ International Conference on Environmental Pollution, Thessaloniki, 149-155.

Filippidis, A., Kassoli-Fournaraki, A. and Tsirambides, A., 1995. The zeolites of Petrota and Metaxades (Thrace) and the kaolins of Leucogia (Macedonia), Greece. In: Aleksiev, B.(ed.) Field Tripe Guide, International Symposium on Natural Zeolites, Sofia, 49-62.

Filippidis, A., Godelitsas, A., Charistos, D., Misaelides, P. and Kassoli-Fournaraki, A., 1996. The chemical behavior of natural zeolites in aqueous environments: Interactions between low-silica zeolites and $1 \mathrm{M} \mathrm{NaCl}$ solutions of different initial pH-values. Applied Clay Science 11: 199-209. 
Filippidis, A., Kantiranis, N., Drakoulis, A. and Vogiatzis, D., 2006. Improvement and protection of the lake Koronia using natural zeolite. Proceedings, $2^{\text {nd }}$ Congress of Aristotle University Environment Council, Thessaloniki, 273-279, In Greek with English summary.

Filippidis, A., Siomos, A., Barbayiannis, N. and Filippidis, S., 2007. Agriculrural and environmental applications using Hellenic Natural Zeolite of Petrota (Evros), Proceedings, Jean Monnet Congress, Veria, Greece, 557-569, In Greek with English summary.

Filippidis, A., Apostolidis, N., Filippidis, S. and Paragios, I., 2008a. Purification of industrial and urban wastewaters, production of odorless and cohesive zeo-sewage sludge using Hellenic Natural Zeolite. Proceedings, Second International Conference on Small and Decentralized Water and Wastewater Treatment Plants, Skiathos, Greece, 403-408.

Filippidis, A., Apostolidis, N., Paragios, I. and Filippidis, S., 2008b. Purification of dye-work and urban wastewaters, production of odorless and cohesive zeo-sewage sludge, using Hellenic Natural Zeolite. CD-Proceedings, $1^{\text {st }}$ International Conference on Hazardous Waste Management, Chania, Greece, 8 pp.

Filippidis, A., Apostolidis, N., Paragios, I. and Filippidis, S., 2008c. Safe management of sewage sludge, produced by treatment of municipal sewage with Hellenic Natural Zeolite. CD-Proceedings, AQUA

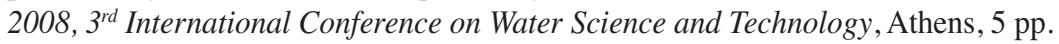

Filippidis, A., Apostolidis, N., Paragios, I. and Filippidis, S., 2008d. Zeolites clean up. Industrial Minerals, April, 68-71.

Filippidis, A., Kantiranis, N., Filippidis, S., Vordogiannis, I., Apostolidis, N. and Paragios, I., 2008e. Purification of Textile-work Waste Waters with Natural Zeolite. Patent Number: 1006140, Industrial Property Organisation, Athens, In Greek.

Filippidis, A., Kantiranis, N., Filippidis, S., Vordogiannis, I., Apostolidis, N. and Paragios, I., 2008f. Purification of Sewage with Natural Zeolite. Patent Number: 1006145, Industrial Property Organisation, Athens, In Greek.

Filippidis, A., Kantiranis, N., Filippidis, S., Vordogiannis, I., Apostolidis, N. and Paragios, I., 2008g. Purification of Tanning-work Waste Waters with Natural Zeolite. Patent Number: 1006146, Industrial Property Organisation, Athens, In Greek.

Filippidis, A., Papastergios, G., Apostolidis, N., Paragios, I., Filippidis, S. and Sikalidis, C., 2009. Odorless and cohesive zeo-sewage sludge produced by Hellenic Natural Zeolite treatment. Proceedings,

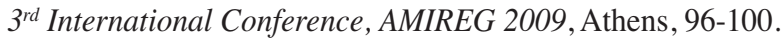

Fokas, P., Zervas, G., Fegeros, K. and Zoiopoulos, P., 2004. Assessment of Pb retention coefficient and nutrient utilization in growing pigs fed diets with added clinoptilolite. Animal Feed Science and Technology 117, 121-129.

Godelitsas, A., Charistos, D., Dwyer, J., Tsipis, C., Filippidis, A., Hatzidimitriou, A. and Pavlidou, E., 1999. Copper (II)-loaded HEU-type zeolite crystals: characterization and evidence of surface complexation with N,N-diethyldithiocarbamate anions. Microporous and Mesoporous Materials 33, 77 87.

Godelitsas, A., Charistos, D., Tsipis, A., Tsipis, C., Filippidis, A., Triantafyllidis, C., Manos, G. and Siapkas, D., 2001. Characterisation of zeolitic materials with a HEU-type structure modified by transition metal elements: Definition of acid sites in Nickel-loaded crystals in the light of experimental and quantum-chemical results. Chemistry European Journal 7, 3705-3721.

Godelitsas, A., Charistos, D., Tsipis, C., Misaelides, P., Filippidis, A. and Schindler, M., 2003. Heterostructures patterned on aluminosilicate microporous substrates: Crystallisation of cobalt (III) tris(N,N-diethyl-dithiocarbamato) on the surface of HEU-type zeolite. Microporous and Mesoporous Materials 61, 69-77. 
Hall, A., Stamatakis, M. and Walsh, J.N., 2000. The Pentalofos zeolitic tuff formation: A giant ion-exchange column. Annales Geologiques des Pays Helleniques 38, 175-192.

Harben, P.W., 2002. The Industrial Minerals HandyBook. Pensord, 409 pp., Blackwood, UK.

Inglezakis, V.J. and Grigoropoulou, H., 2004. Effects of operating conditions on the removal of heavy metals by zeolite in fixed bed reactors. Journal of Hazardous Materials B112,37-43.

Inglezakis, V.J., Loizidou, M.M. and Grigoropoulou, H.P., 2004. Ion exchange studies on natural and modified zeolites and the concept of exchange site accessibility. Journal of Colloid and Interface Science 275, 570-576.

Inglezakis, V.J., Zorpas, A.A., Loizidou, M.D. and Grigoropoulou, H.P., 2005. The effect of competitive cations and anions on ion exchange of heavy metals. Separation and Purification Technology 46, 202-207.

Kantiranis, N., Chrissafis, C., Filippidis, A. and Paraskevopoulos, K., 2006. Thermal distinction of HEUtype mineral phases contained in Greek zeolite-rich volcaniclastic tuffs. European Journal of Mineralogy 18, 509-516.

Kassoli-Fournaraki, A., Stamatakis, M., Hall, A., Filippidis, A., Michailidis, K., Tsirambides, A. and Koutles, Th., 2000. The Ca-rich clinoptilolite deposit of Pentalofos, Thrace, Greece. In: Colella, C. \& Mumpton, F.A.(eds) Natural Zeolites for the Third Millennium, De Frede Editore, Napoli, 193-202.

Katranas, Th., Vlessidis, A., Tsiatouras, V., Triantafyllidis, K. and Evmiridis, N., 2003. Dehydrogenation of propane over natural clinoptilolite zeolites. Microporous and Mesoporous Materials 61, 189-198.

Kirov, G.N., Filippidis, A., Tsirambidis, A., Tzvetanov, R.G. and Kassoli-Fournaraki, A., 1990. Zeolitebearing rocks in Petrota area (Eastern Rhodope Massif, Greece). Geologica Rhodopica 2, 500-511.

Koshiaris, G., Marantos, I., Tsirambides, A., Stamatakis, M.G., Kassoli-Fournaraki, A. and Filippidis, A., 2002. The zeolite deposits of Thrace (North-Eastern Greece). Field Trip Guide, $6^{\text {th }}$ International Conference on Natural Zeolites, Thessaloniki, 23 pp.

Krestou, A., Xenidis, A. and Panias, D., 2003. Mechanism of aqueous uranium (VI) uptake by natural zeolitic tuff. Minerals Engineering 16, 1363-1370.

Kyriakis, S.C., Papaioannou, D.S., Alexopoulos, C., Polizopoulou, Z., Tzika, E.D. and Kyriakis, C.S., 2002. Experimental studies on safety and efficacy of the dietary use of a clinoptilolite-rich tuff in sows: a review of recent research in Greece. Microporous and Mesoporous Materials 51, 65-74.

Marantos, I. and Perdikatsis, V., 1994. Study of the mineralogical composition, dehydration / adsorption of water and ion exchange capacity of zeolitic tuffs from Petrota-Pentalofos area, N. Evros. Bull. Geol. Soc. Greece 30/3, 311-321, In Greek with English abstract.

Misaelides, P., Godelitsas, A., Haristos, D., Noli, F., Filippidis, A. and Sikalidis, C., 1993. Determination of heavy metal uptake by the sodium form of heulandite using radiochemical techniques. Geologica Carpathica - Series Clays 44/2, 115-119.

Misaelides, P., Godelitsas, A., Filippidis, A., Charistos, D. and Anousis, I., 1995. Thorium and uranium uptake by natural zeolitic materials. The Science of the Total Environment 173/174, 237-246.

Moirou, A., Xenidis, A. and Paspaliaris, I., 2001. Stabilization Pb, Zn, and Cd- contaminated soil by means of natural zeolites. Soil and Sediment Contamination 10/3, 251-267.

Papaioannou, D.S., Kyriakis, S.C., Papasteriadis, A., Roumbies, N., Yannakopoulos, A. and Alexopoulos, C., 2002a. A field study on the effect of in-feed inclusion of a natural zeolite (clinoptilolite) on health status and performance of sows/gilts and their litters. Research in Veterinary Science 72, 5159.

Papaioannou, D., Kyriakis, S., Papasteriadis, A., Roumbies, N., Yannakopoulos, A. and Alexopoulos, C., 2002b. Effect of in-feed inclusion of a natural zeolite (clinoptilolite) on certain vitamin, macro and 
trace element concentrations in the blood, liver and kidney tissues of sows. Research in Veterinary Science 72, 61-68.

Perraki, Th. and Orfanoudaki, A., 2004. Mineralogical study of zeolites from Pentalofos area, Thrace, Greece. Applied Clay Science 25, 9-16.

Perraki, Th., Kakali, G. and Kontoleon, F., 2003. The effect of natural zeolites on the early hydration of Portland cement. Microporous and Mesoporous Materials 61, 205-212.

Pond, W.G. and Mumpton, F.A., 1984.Zeo-Agriculture, Use of Natural Zeolites in Agriculture and Aquaculture, I.C.N.Z., 305 pp., Brockport, NY.

Savvas, D., Samantouros, K., Paralemos, D., Vlachakos, G., Stamatakis, M. and Vassilatos, C., 2002. Yield and nutrient status in the root environment of tomatoes (Lycopersicon esculentum) grown on chemically active and inactive inorganic substrates. Acta Horticulturae 644, 377-383.

Stamatakis, M., Hall, A., Lutat, U. and Walsh, J.N., 1998. Mineralogy, origin and commercial value of the zeolite-rich tuffs in the Petrota-Pentalofos area, Evros county, Greece. Estudios Geologicos 54, $3-15$.

Stamatakis, M., Koukouzas, N., Vassilatos, Ch., Kamenou, E. and Samantouros, K., 2001. The zeolites from Evros region, Northern Greece: A potential use as cultivation substrate in hydroponics. Acta Horticulturae 548, 93-103.

Tsitsishvili, G.V., Andronikashvili, T.G., Kirov, G.N. and Filizova, L.D., 1992. Natural Zeolites, Ellis Horwood Ltd, 295 pp., Chichester, West Sussex.

Warchol, J., Misaelides, P., Petrus, R. and Zamboulis, D., 2006. Preparation and application of organomodified zeolitic material in the removal of chromates and iodides. Journal of Hazardous Materials B137, 1410-1416.

Vlessidis, A.G., Triantafillidis, C.S . and Evmiridis, N.P., 2001. Removal and recovery of p-phenylenediamines developing coumpounds from photofinishing lab washwater using clinoptilolite tuffs from Greece. Water Research 35, 1603-1608.

Yannakopoulos, A., Tserveni-Gousi, A., Kassoli-Fournaraki, A., Tsirambides, A., Michailidis, K., Filippidis, A. and Lutat, U., 2000. Effects of dietary clinoptilolite-rich tuff on the performance of growing-finishing pigs. In: Colella, C. \& Mumpton, F.A.(eds) Natural Zeolites for the Third Millennium, De Frede Editore, Napoli, 471-481.

Zorpas, A.A., Constantinides, T., Vlyssides, A.G., Haralambous, I. and Loizidou, M., 2000a. Heavy metal uptake by natural zeolite and metals partitioning in sewage sludge compost. Bioresource Technology 72, 113-119.

Zorpas, A.A., Kapetanios, E., Zorpas, G.A., Karlis, P., Vlyssides, A., Haralambous, I. and Loizidou, M., 2000b. Compost produced from organic fraction of municipal solid waste, primary stabilized sewage sludge and natural zeolite. Journal of Hazardous Materials B77, 149-159. 